\title{
Differential expression of micro RNA-29 family in non-diabetic adults of diabetic and non-diabetic parents
}

\author{
Uzair Abbas ${ }^{* *}$, Bushra Imdad ${ }^{1}$, Sikander Adil Mughal', Israr Ahmed Baloch², Afshan Mehboob Khan ${ }^{1}$ and \\ Durr-e-Sameen Kamran ${ }^{3}$
}

\begin{abstract}
Objective: MicroRNAs are known to regulate $60 \%$ of genes at post translational level. MicroRNAs including Micro RNA-29 family play a vital role in cellular activities and have validate role in numerous metabolic disorders inclusive of diabetes mellitus and its complications. While micro RNA profile changes years before the occurrence of disease. This cross-sectional study was conducted in non-diabetic adults of diabetic and non-diabetic parents to explore the early changes in expression of micro RNA-29 family as it can be served as early biomarker of type 2 diabetes in non-diabetic adults. This study was conducted from January 2019 to January 2021. Micro RNA was extracted from plasma of 50 participants and expression was compared through qPCR. While data was analyzed through SPSS version 21.0.
\end{abstract}

Results: 29a and 29b had lower expression in participants with family history of DM compared to those having no family history of DM $(P<0.0001)$. While micro RNA $29 \mathrm{c}$ was found to be significantly higher in participants with positive family history of type 2 diabetes as compared to those without family history of diabetes $(P=0.001)$.

Keywords: Diabetes mellitus, Early diagnosis, Biomarker, Micro RNA

\section{Introduction}

Diabetes Mellitus is a complex and multi factorial disease which is caused either by insufficient production of insulin or insulin resistance by the cells or both [1]. Presently there are more than 500 million prevalent cases of type 2 diabetes across the world [2]. In Pakistan, type 2 DM is $16.98 \%$ prevalent [3]. Early diagnosis of the diabetes holds an immense importance because if it is not diagnosed timely than it may have very unsound effects on population leading to higher rates of hospitalizations due to the related complications which are dangerous and widely affect the quality of life even early death [4].

\footnotetext{
*Correspondence: uzair.abbas@duhs.edu.pk

1 Present Address: Department of Physiology, Dow University of Health

Sciences, Karachi, Pakistan

Full list of author information is available at the end of the article
}

The miRNA-29 group has been known to become important regulator of glucose metabolism and has altered expression in diabetics due to its different targets [5-9]. So, it is supposed to be important in studying diabetes and its related micro and macro vascular complications. Researches have reported up regulation of MiR-29 in target insulin tissues of animal models and in serum of diabetic patients along with diabetic risks such as retinopathy, kidney disease and cardiovascular disorders. Since the discovery of micro-RNA multiple researches have been directed to correlate the role of micro RNAs in diabetes and its associated risks. MiR-29 knockout mice were observed having high fasting glucose and impaired serum insulin release [5]. MiR-29 was also increased by two folds in hepatocytes of diabetic mouse indicate negative regulation of gluconeogenesis through suppressing glucose-6-phosphatase [10]. It is also supposed that over expression inhibits PEPCK gene which encodes 
phosphoenolpyruvate carboxykinase- an enzyme which is used in the pathway of gluconeogenesis [11], and when over expressed in vitro in presence of high insulin and high glucose in 3T3-L1 adipocytes, there was less amount of glucose uptake probably through disturbing AKT phosphorylation [11]. Increased amount of blood glucose causes inappropriate cell signaling via triggering and disturbing multiple inflammatory and fibrotic pathways in cells of vessels which cause to increase cardiac risks like coronary artery disease, atherosclerosis, stroke and hypertension. Micro RNAs like miR-29, miR-30 and miR-21 are responsible to regulate the fibrotic genes such as collagens and connecting tissue growth factor (CTGF) which leads to fibrosis which is related to heart failure and myocardial infarction [4]. Collagen and VEGF are known targets of MiR-29 [12].When clinical importance of DM related micro RNAs was investigated in the serum of 3 groups, the study showed differential expression of microRNAs when compared for newly diagnosed diabetic group with pre-diabetic and suspected diabetic, however no marked difference was noted among prediabetic and suspected diabetic groups in which MiR-29a was also destructed in type 1 diabetes was significantly different in diseased and non-diseased [13]. Years ago the onset and diagnosis of the diabetes the MiRNAs of plasma level changes and can differentiate the patients with a higher chance of having diabetes from healthy measures [14] The whole data suggested the involvement of micro RNA 29 family in pathophysiology of diabetes mellitus. The objective of this study was to compare the expression of micro RNA-29 family in non-diabetic adults of diabetic and non-diabetic parents, so that it may be used as bio marker for early detection of diabetes in non-diabetic adults.

\section{Main text}

\section{Material and methods}

\section{Study design and duration}

This was a cross-sectional study conducted from January 2019 to January 2021.

\section{Sample size calculation}

Using Lahr's theorem from NCSS PASS software, with $95 \%$ confident interval and $80 \%$ power of the test, the sample size came to be 25 for each group. Sampling technique was purposive convenient type.

\section{Participants}

Participants were healthy non-diabetic workers and students of Dow University of Health Sciences, Karachi, Pakistan. Participants having age between 18 to 30 years were included after testing for $\mathrm{HbA1c}$ according to $\mathrm{WHO}$ criteria. While those having any metabolic disorder or
HbA1c in rages of pre-diabetes were excluded. Informed written consent was taken from the participants. 50 blood samples were obtained. 25 from each category i.e. with and without parental history of type 2 diabetes mellitus.

\section{Ethical approval}

The study was approved by institutional review board (IRB) of Dow University of Health Sciences, Karachi, Pakistan (IRB letter no. 2018/1045).

\section{Sample preparation}

$3 \mathrm{ml}$ blood were collected from participants. Consent was taken from every patient and informed about the study. Sample was centrifuged at $6500 \mathrm{rmp}$ for $5 \mathrm{~min}$ and plasma was separated and stored at -80 for further process.

\section{Extraction and quantification of miRNA}

Micro RNA was extracted from samples by using a mirVana ${ }^{\circledR}$ micro RNA isolation kit (Ambion, USA) according to manufacturer's guidelines.

Extracted micro RNA was then used to form cDNA separately for microRNA 29-a, 29-b, 29c and internal control i.e. U6 using specific RT primers. The synthesized cDNA was used for qRT-PCR by using Maxima SYBR green qPCR master mix (ThermoScientific, USA) according to manufacturer's instructions and expression of MiR-29a, b and c of samples were normalized to U6. Total $25 \mu \mathrm{l}$ of reaction volume was attained by adding $12.5 \mu \mathrm{l}$ of SYBR green master mix, $2 \mu \mathrm{l}$ of cDNA along with $9.5 \mu \mathrm{l}$ of $\mathrm{dH}_{2} \mathrm{O}, 0.5 \mu \mathrm{l}(10 \mathrm{pmol} / \mu \mathrm{l})$ of reverse and forward primers. Each sample was run in triplicate. A comparative delta delta-CT formula was used for comparison of targeted micro RNA. Expression of micro RNA was normalized with SnRNA-u6, and comparative values were expressed as $2^{-\Delta \Delta C T}$.

\section{Statistical analysis}

Data were compiled in MS Excel and analyzed in SPSS version 21.0. Descriptive statistics expressed in terms of frequency with percentage for categorical variables such as sex, smoking status, exercise status, family history etc. while mean with standard deviation for continuous variables like age, BMI and micro RNA expression were taken.

Repeated Measures ANOVA was used to compare average expression within three members Correlation coefficients between $\mathrm{HbA1C}$, BMI and fold changes were measured by Spearman's method. With 95\% confidence interval, $\mathrm{P}$ value less than 0.05 was considered as significant. 


\section{Results}

The demographic data of groups were summarized in Additional file 1: Table S1. When expression of micro RNA was compared within groups separately, it was found that micro RNA 29c was up regulated in youngster with positive family history of diabetes as compared to $29 \mathrm{~b}$ and $29 \mathrm{a}(\mathrm{P}<0.001)$ whereas, no significant difference was found in expression of $29 \mathrm{a}$ and $29 \mathrm{~b}$ in them $(\mathrm{P}=0.299)$ (Fig. 1). Whereas higher expression of micro RNA 29a was found as compared to $29 \mathrm{~b}$ and $29 \mathrm{c}$ in youngsters who had no family history of diabetes
$(\mathrm{P} \leq 0.001)$. While no significant differential expression was found between $29 \mathrm{~b}$ and $29 \mathrm{c}(\mathrm{P}=0.749)$ (Fig. 2).

When the expression was compared between the groups with respect to internal control SnRNA-U6, the result showed that micro RNA 29a, 29b and 29c showed significant difference between the both the groups i.e. participants with family history of T2DM and participants without family history of DM $(\mathrm{P}<0.001)$. Additional analysis by post-hoc Tukey test showed marked difference of 29a between both groups $(\mathrm{P}<0.0001)$, in which participants with family history of DM had lower

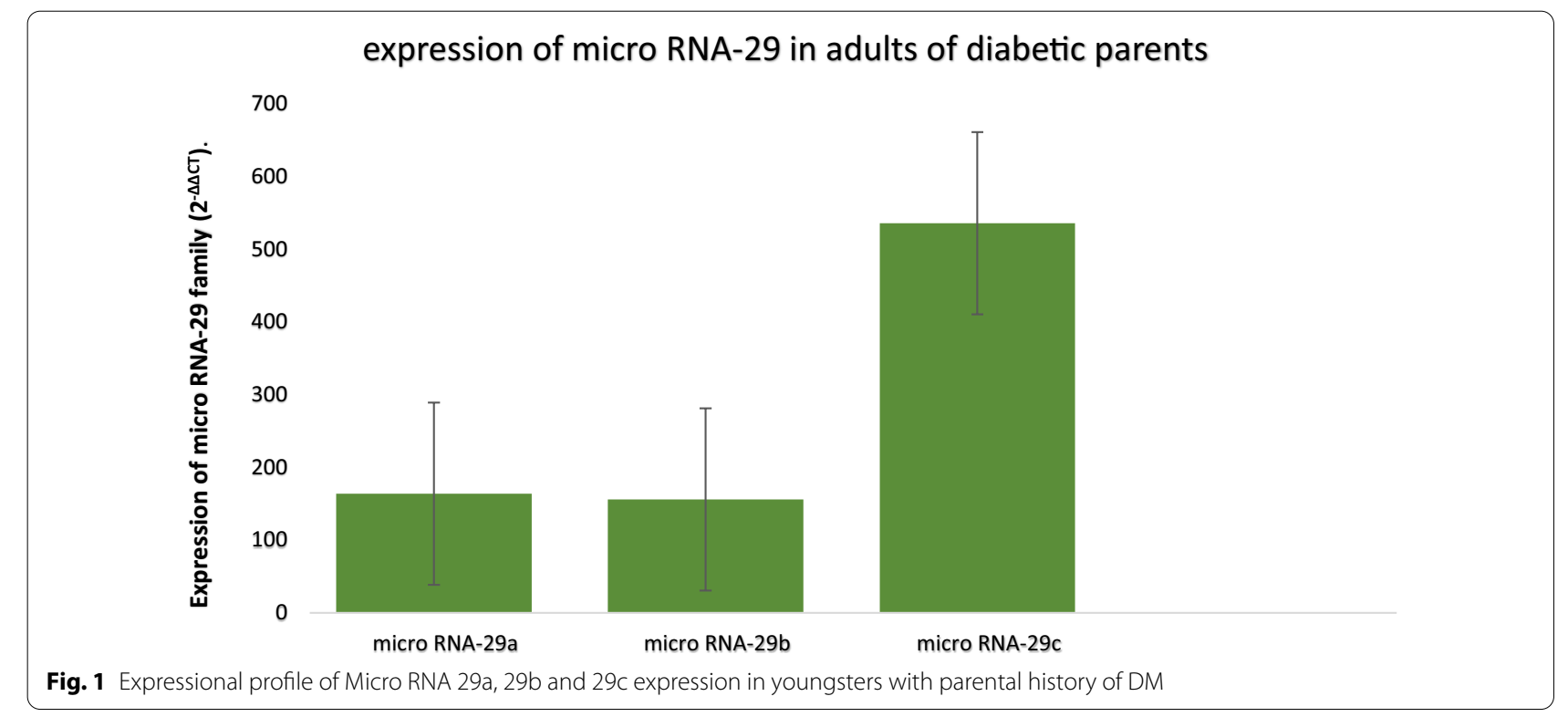

expression of micro RNA-29 in youngsters of non-diabetic parents

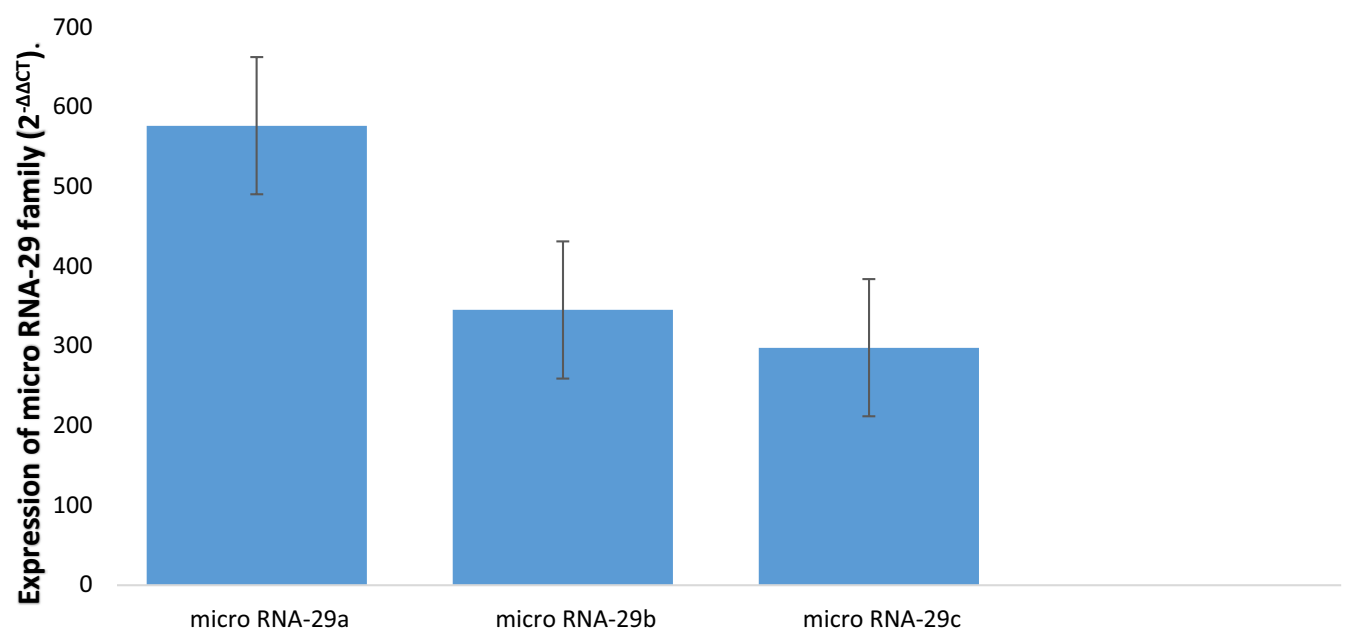

Fig. 2 Expressional profile of Micro RNA 29a, 29b and 29c expression in youngsters with no parental history of DM 
expression of micro RNA-29a as compared to those having no family history of DM. Micro RNA 29b was also found to be down regulated in participants with family history of DM as compared to other group $(\mathrm{P}<0.0001)$. However, Micro RNA 29c was found to be significantly higher in participants with positive family history of DM as compared to those without family history $(\mathrm{P}=0.001)$ (Fig. 3). The fold change of micro RNA of these patients was then compared with different variables like BMI and $\mathrm{HbA} 1 \mathrm{c}$ to know the correlation of these variables with expression of microRNA 29 family which revealed no any significant correlation with BMI and HbA1c of participants. [(BMI: 29a, $\mathrm{R}=-0.093, \mathrm{p}=0.0350 ; 29 \mathrm{~b}$, $\mathrm{R}=-0.066, \mathrm{p}=0.508 ; 29 \mathrm{c}, \mathrm{R}=0.124, \mathrm{p}=0.214)$. (HbA1c: $29 \mathrm{a}, \mathrm{R}=-0.89, \mathrm{p}=0.078 ; 29 \mathrm{~b}, \mathrm{R}=-0.099, \mathrm{p}=0.023$; $29 \mathrm{c}, \mathrm{R}=0.135, \mathrm{p}=0.322$ )] (Additional file 2: Figures $\mathrm{S} 1$ and S2).

\section{Discussion}

Since the discovery of micro RNA, the initial studies were performed in animal modules to evaluate the functions and pathogenesis of diabetes mellitus related to micro RNA. Multiple studies were carried out to detect and compare the expression of different diabetes related micro RNA in diabetic, pre-diabetic and non-diabetic populations. This study is first of its kind that has evaluated the differential expression of micro RNA-29 in two different non-diabetic population i.e. with and without family history of T2DM to detect possible early changes in micro RNA expression. The effort was made as it can serve as a potential biomarker for early diagnosis of type 2 diabetes mellitus.
This study shows the differential expression of micro RNA-29 family (29a, 29b, 29c) between non-diabetic youngsters with and without family history of DM. This study was however, comprised of only non-diabetic youngsters, but its results correlate with many other studies from past which were performed in different study groups like diabetic, pre-diabetic and non-diabetics.

This research showed micro RNA 29a was down regulated in participants with positive family history of diabetes which is in accordance with many studies; Lin et al. quantified miR-29a and was found down regulated in glomeruli of diabetic mice [15] while another study revealed MiR-29a knockout mice showed higher blood glucose levels when compared with wild type due defect in insulin secretion while insulin production was found to be normal [5]. Satake et al. also reported down regulation of micro RNA 29a in plasma of type 1 diabetic patients [16]. Whereas in contrary with our study, Kerolina et al. reported the higher expression of micro RNA 29 a in serum of newly diagnosed type 2 diabetic patients in order to identify the possible predictors of type 2 diabetes [17]. Dooley et al. reported micro RNA 29a as positive regulator of insulin secretion in vivo and here in our study we found down regulation of micro RNA 29a which may lead to decreased insulin secretion in future and cause insulin insensitivity [5].

Here in this study it was found that micro RNA 29b also had low expression which is similar to a study performed on diabetic rats and reported that decreased micro RNA 29 family expression increases the blood glucose levels via interacting negatively with hepatic gluconeogenesis and increase levels of PGC-1a and G6Pase, which are the direct targets of 29 family, which is strongly in favor of

expression of micro RNA-29 family in study groups

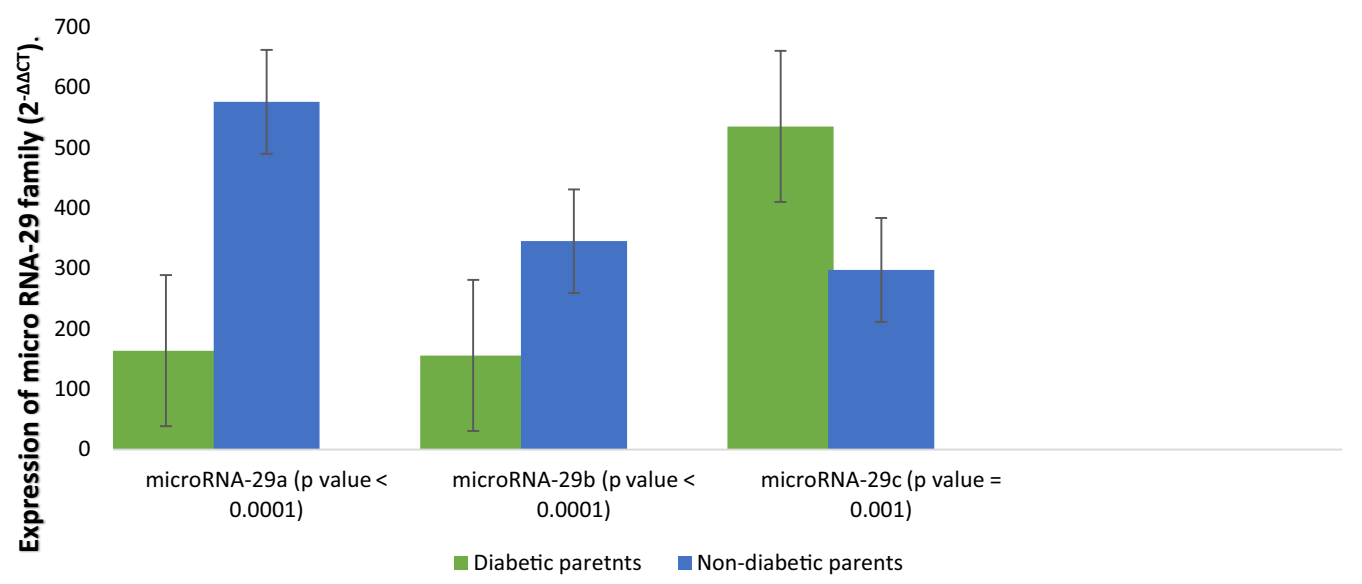

Fig. 3 Differential Expression of micro RNAs 29a, 29b and 29c showing significant difference between participants of diabetic and non-diabetic parents 
this study and lower expression of $29 \mathrm{~b}$ may cause higher glucose levels in future [10]. Chen et al. reported the down regulation of micro RNA $29 \mathrm{~b}$ in $\mathrm{db} / \mathrm{db}$ mice which caused increased fibrosis and increased inflammation in the kidney of mice which leads to diabetic nephropathy, which definitely favor these results and also suggests the disturbed level of micro RNA 29 family may lead to diabetic complications [18]. Peng et al. also found decreased expression of micro RNA-29b in 83 type 2 diabetic patients [19]. Interestingly, another study revealed an ethnicity specific profile of micro RNA related with T2DM compared with controls between Iraqi and Swedish population also came up with differential expression of micro RNA 29b between the Iraqi and Swedish population which supports this study [20]. However, Kerolina et al. stated the up regulation of $29 \mathrm{~b}$ in whole blood of 36 T2DM patients along with deregulation of micro RNA29c [17].

This study also focused on correlation of variables like BMI and HbA1c of diabetic patients with expression of miRNA-29 family but we did not find any correlation of age, BMI and HbA1c with miR-29 expression (Additional file 2: Figures S1a-S2c). While in contrast, different studies have worked on correlation of variables like BMI, FMI, insulin secretion, serum lipids and other metabolites with different micro RNAs in which different correlation was found. Cui et al. found a positive correlation between BMI and FMI with miR-222, miR-486, miR-146b, miR15b, miR-146a, miR-20a, miR-20b, and miR-197 [21]. In another study $\mathrm{HbA} 1 \mathrm{c}$ was found to be negatively correlated with miR-126 in 68 T1DM patients [22].

\section{Conclusion}

As micro RNA-29 has proved roll in DM, significant differential expression of micro RNA-29a, 29b and 29c was found between the study groups. As genetic predisposition is one of the cause of type 2 diabetes mellitus, these results suggest possible early genetic changes in nondiabetic adults with positive family history of DM and the same pattern of micro RNA-29 expression is found in patients with diabetes in many studies which are suggestive of involvement of this micro RNA in diabetes and may have potential to serve as early biomarker in type 2 diabetes.

\section{Limitations}

The sample size was small and study population was very concise. Moreover, the micro RNA profile of parents could not be compared with children due to high cost and inconvenience.
Abbreviations

DM: Diabetes mellitus; MiRNA: Micro ribose nucleic acid; VEGF: Vascular endothelial growth factor.

\section{Supplementary Information}

The online version contains supplementary material available at https://doi. org/10.1186/s13104-021-05703-8.

Additional file 1: Table S1. Summary of demographic profile of participants of the study $(n=50)$.

Additional file 2: Figure S1. a b and c shows no correlation of micro RNA-29a, $29 b$ and 29 c with HbA1c of participants. $(n=50)$. Figure S2. $a b$ and c shows no any correlation of micro RNA-29a, 29b and 29c with BMl of participants $(n=50)$.

\section{Acknowledgements}

We acknowledge the students of Dow International Medical College and participants of the study who willingly participated.

\section{Authors' contributions}

Conception/design of the work: UA, BI. Data collection, data analysis and interpretation: UA, SAM, IAB. Drafting the article: UA, AMK. Critical revision of the article, and final approval: UA, DSK. All authors read and approved the final manuscript

Funding

This study was not funded by any funding agency.

\section{Availability of data}

All data has been included in the study however it is available with the corresponding author and may be provided on request.

\section{Declarations}

Ethical approval and consent to participate

Informed written consent was taken from the participants. The study was approved by institutional review board (IRB) of Dow University of Health Sciences, Karachi, Pakistan (IRB letter no. 2018/1045).

Consent to publish

Not applicable.

Competing interests

There is no conflict of interest either personal or financial among the authors.

\section{Author details}

${ }_{1}^{1}$ Present Address: Department of Physiology, Dow University of Health Sciences, Karachi, Pakistan. ${ }^{2}$ Department of Education and Research Mayo Clinic, Jacksonville, FL, USA. ${ }^{3}$ Department of Pathology, Dow University of Health Sciences, Karachi, Pakistan.

Received: 19 April 2021 Accepted: 18 July 2021

Published online: 28 July 2021

References

1. Guay C, Regazzi R. Circulating microRNAs as novel biomarkers for diabetes mellitus. Nat Rev Endocrinol. 2013;9(9):513.

2. Kaiser $A B$, Zhang $N$, Van der Pluijm W. Global prevalence of type 2 diabetes over the next ten years (2018-2028). Am Diabetes Assoc. 2018. https://doi.org/10.2337/db18-202-LB.

3. Aamir AH, Ul-Haq Z, Mahar SA, Qureshi FM, Ahmad I, Jawa A, et al. Diabetes prevalence survey of Pakistan (DPS-PAK): prevalence of type 2 diabetes mellitus and prediabetes using $\mathrm{HbA} 1 \mathrm{c}$ : a population-based survey from Pakistan. BMJ Open. 2019;9(2):e025300. 
4. DiStefano JK, Taila M, Alvarez ML. Emerging roles for miRNAs in the development, diagnosis, and treatment of diabetic nephropathy. Curr Diabetes Rep. 2013;13(4):582-91.

5. Dooley J, Garcia-Perez JE, Sreenivasan J, Schlenner SM, Vangoitsenhoven R, Papadopoulou AS, et al. The microRNA-29 family dictates the balance between homeostatic and pathological glucose handling in diabetes and obesity. Diabetes. 2016;65(1):53-61.

6. Slusarz A, Pulakat L. The two faces of miR-29. J Cardiovasc Med (Hagerstown Md). 2015:16(7):480.

7. Kantharidis P, Wang B, Carew RM, Lan HYJD. Diabetes complications: the microRNA perspective. Diabetes. 2011;60(7):1832-7.

8. Ruiz MA, Chakrabarti S. MicroRNAs: the underlying mediators of pathogenetic processes in vascular complications of diabetes. Can J Diabetes. 2013;37(5):339-44.

9. Silva VA, Polesskaya A, Sousa TA, Corrêa VM, André ND, Reis RI, et al. Expression and cellular localization of microRNA-29b and RAX, an activator of the RNA-dependent protein kinase (PKR), in the retina of streptozotocin-induced diabetic rats. Mol Vis. 2011;17:2228.

10. Liang J, Liu C, Qiao A, Cui Y, Zhang H, Cui A, et al. MicroRNA-29a-C decrease fasting blood glucose levels by negatively regulating hepatic gluconeogenesis. J Hepatol. 2013;58(3):535-42.

11. Pandey AK, Verma G, Vig S, Srivastava S, Srivastava AK, Datta MJM, et al. miR-29a levels are elevated in the $\mathrm{db} / \mathrm{db}$ mice liver and its overexpression leads to attenuation of insulin action on PEPCK gene expression in HepG2 cells. Mol Cell Endocrinol. 2011;332(1-2):125-33.

12. McClelland AD, Kantharidis P. microRNA in the development of diabetic complications. Clin Sci. 2014;126(2):95-110.

13. Raffort J, Hinault C, Dumortier O, Van Obberghen EJD. Circulating microRNAs and diabetes: potential applications in medical practice. Diabetologia. 2015;58(9):1978-92.

14. Zampetaki A, Kiechl S, Drozdov I, Willeit P, Mayr U, Prokopi M, et al. Plasma microRNA profiling reveals loss of endothelial miR-126 and other microRNAs in type 2 diabetes. Circ Res. 2010;107(6):810-7.
15. Lin C-L, Lee P-H, Hsu Y-C, Lei C-C, Ko J-Y, Chuang P-C, et al. MicroRNA-29a promotion of nephrin acetylation ameliorates hyperglycemia-induced podocyte dysfunction. J Am Soc Nephrol. 2014;25(8):1698-709.

16. Pezzolesi MG, Satake E, McDonnell KP, Major M, Smiles AM, Krolewski ASJD. Circulating TGF- $\beta 1$-regulated miRNAs and the risk of rapid progression to ESRD in type 1 diabetes. Diabetes. 2015;64(9):3285-93.

17. Karolina DS, Armugam A, Tavintharan S, Wong MT, Lim SC, Sum CF, et al. MicroRNA 144 impairs insulin signaling by inhibiting the expression of insulin receptor substrate 1 in type 2 diabetes mellitus. PLoS ONE. 2011;6(8):e22839

18. Chen H-Y, Zhong $X$, Huang XR, Meng X-M, You Y, Chung AC, et al. MicroRNA-29b inhibits diabetic nephropathy in $\mathrm{db} / \mathrm{db}$ mice. Mol Ther. 2014;22(4):842-53.

19. Peng H, Zhong M, Zhao W, Wang C, Zhang J, Liu X, et al. Urinary miR-29 correlates with albuminuria and carotid intima-media thickness in type 2 diabetes patients. PLoS ONE. 2013;8(12):e82607.

20. Wang $X$, Sundquist J, Zöller B, Memon AA, Palmér K, Sundquist K, et al. Determination of 14 circulating microRNAs in Swedes and Iraqis with and without diabetes mellitus type 2. PLoS ONE. 2014;9(1):e86792.

21. Cui X, You L, Zhu L, Wang X, Zhou Y, Li Y, et al. Change in circulating microRNA profile of obese children indicates future risk of adult diabetes. Metabolism. 2018;78:95-105.

22. Osipova J, Fischer DC, Dangwal S, Volkmann I, Widera C, Schwarz K, et al. Diabetes-associated microRNAs in pediatric patients with type 1 diabetes mellitus: a cross-sectional cohort study. J Clin Endocrinol Metab. 2014;99(9):E1661-5.

\section{Publisher's Note}

Springer Nature remains neutral with regard to jurisdictional claims in published maps and institutional affiliations.
Ready to submit your research? Choose BMC and benefit from:

- fast, convenient online submission

- thorough peer review by experienced researchers in your field

- rapid publication on acceptance

- support for research data, including large and complex data types

- gold Open Access which fosters wider collaboration and increased citations

- maximum visibility for your research: over $100 \mathrm{M}$ website views per year

At BMC, research is always in progress.

Learn more biomedcentral.com/submissions 